\title{
Peningkatan Pengetahuan Status Cairan melalui “Puri” (Periksa Urin Sendiri) pada Lansia
}

\author{
Bejo Danang Saputra ${ }^{1}$; Wishnu Subroto²; Ahmad Subandi ${ }^{3}$ \\ ${ }^{1}$ Prodi S1 Keperawatan, ${ }^{2}$ Prodi D3 Fisioterapi, ${ }^{3}$ Prodi D3 Keperawatan, \\ STIKES Al-Irsyad Al-Islamiyyah, Jalan Cerme No 24 Sidanegara Cilacap 53223 \\ Email korespondensi : jodanang84@gmail.com
}

\begin{abstract}
Abstrak
Masa lansia sangat rentan mengalami gangguan cairan baik kekurangan caitan maupun kelebihan cairan yang akan berdampak pada kesehatan lansia tersebut. Untuk mengatasi masalah tersebut dapat dilakukan dengan melakukan pemeriksaan urin sendiri (PURI). Tujuan pengabdian ini adalah untuk meningkatkan pengetahuan dan keterampilan lansia tentang status cairan tubuh melalui pemeriksaan urin sendiri. Metode pengabdian dilakukan dengan melakukan penyuluhan untuk meningkatkan pengetahuan dan pemeriksaan urin untuk meningkatkan keterampilan lansia untuk mengetahui status cairan tubuh. Hasil pengabdian menunjukan adanya peningkatan pengetahuan lansia dengan nilai rata-rata 9,20 dibandingkan sebelum dilakukan penyuluhan sebesar 8,75. Hasil pemeriksaan urin lansia sebagian besar mengalami dehidrasi ringan sebanyak 7 orang $(58 \%)$. Kesimpulan pengabdian ini dapat meningkatkan pengetahuan dan keterampilan lansia tentang status cairan dan cara pemeriksaan urin secara mandiri.
\end{abstract}

Kata Kunci : Lansia, cairan tubuh, PURI

\begin{abstract}
The elderly are very susceptible to fluid disorders, both lack of fluids / dehydration and excess fluids which will have an impact on the health of the elderly. To overcome this problem can be done by doing a urine self-examination (PURI). The aim of this service is to improve the knowledge and skills of the elderly about the status of body fluids through self-examination of urine. The service method is carried out by providing counseling to increase knowledge and urine examinations to improve the skills of the elderly to determine the status of body fluids. The service results showed an increase in the knowledge of the elderly with an average value of 9.20 compared to before the extension was done, which was 8.75. The results of urine examination of the elderly mostly experienced mild dehydration as many as 7 people (58\%). The conclusion of this service can increase the knowledge and skills of the elderly about fluid status and how to independently examine urine.

The problem of the elderly (elderly) will be faced by everyone and develop into more complex
\end{abstract}

Keywords: Elderly, body fluids, PURI 


\section{PENDAHULUAN}

Indonesia mengalami peningkatan populasi penduduk lanjut usia (lansia) yang cukup pesat dari 4,48 \% pada tahun 1971 (5,3 juta jiwa) menjadi 9,77\% pada tahun 2010 (23,9 juta jiwa) dan diprediksi akan terjadi ledakan jumlah penduduk lansia sebesar 11,34\% atau sekitar 28,8 juta jiwa pada tahun 2020. Masalah lanjut usia akan dihadapi setiap insan dan berkembang menjadi masalah yang lebih kompleks yang salah satunya masalah kebutuhan cairan (Fatmah, 2010)

Sekitar $70 \%$ tubuh manusia terdiri dari air. Air merupakan salah satu zat gizi penting bagi kesehatan tubuh. Keseimbangan air tubuh dikontrol dengan pengaturan asupan dan ekskresi cairan. Normalnya, asupan air dipengaruhi oleh rasa haus yang merupakan pertahanan tubuh terhadap kekurangan cairan (Popkin \& D'Anci, 2010). Selama penuaan terjadi sejumlah perubahan fisiologis sehingga menempatkan lansia lebih berisiko dehidrasi, secara progresif akan menjadi masalah dengan meningkatnya populasi yang menua dan meningkatkan kebutuhan yang lebih besar pada pelayanan sosial dan kesehatan (Vivanti \& Harvey, 2010)

Rasa haus merupakan indikator dehidrasi akut namun sensasi haus pada lansia sudah menurun sehingga asupan air pada mereka harus lebih diperhatikan. Cadangan air pada tubuh lansia jumlahnya berkurang akibat proporsi lemak yang lebih besar dan penurunan lean body mass. Kebanyakan lansia tidak mengetahui berapa banyak cairan yang mereka butuhkan. Menurunnya konsumsi cairan dan berkurangnya cairan tubuh dapat mengganggu keseimbangan air pada lansia. Penurunan sensasi haus pada lansia dapat menjelaskan mengapa lansia sering kurang minum, mereka mungkin juga sengaja membatasi konsumsi cairan untuk menghindari frekuensi berkemih, terutama pada mereka yang memiliki gangguan mobilitas (Hardinsyah et al, 2010).

Selain masalah kekurangan cairan, lansia juga bisa mengalami kelebihan cairan yang hal ini dapat berakibat buruk bagi kesehatannya. Berdasarkan hasil penelitian terhadap lansia ditemukan bahwa asupan cairan yang terlalu banyak memiliki kemungkinan $78 \%$ menjadi pemicu terjadinya hiponatremia. Hiponatremia akan menimbulkan beberapa komplikasi seperti edema otak. Jika berlanjut bisa mengakibatkan kerusakan jaringan otak yang menetap. Hiponatremia kronis ringan juga bisa berisiko patah tulang pada manula karena kesadaran menurun (Nugroho, 2000).

Perhimpunan Dokter Gizi Medik Indonesia (PDGMI) menggalakkan Periksa Urin Sendiri (PURI) dengan grafik warna urin sebagai upaya mencegah dehidrasi sedini mungkin. 
Meskipun diperlukan pemeriksaan lebih lanjut, namun grafik warna urin memiliki potensi sebagai teknologi murah dan cepat untuk memantau dehidrasi (Jequier E et al, 2010). Grafik warna PURI terdiri dari 8 warna yaitu mulai dari yang bewarna jernih sampai warna kuning keruh/pekat. Warna urin jernih menunjukan status hidrasi yang baik, sedangkan warna urin kuning pekat menunjukan asupan cairan yang kurang dan harus segera mendapat asupan cairan agar kondisi cairan tubuh dapat seimbang.

Desa Slarang merupakan salah satu desa yang termasuk dalam wilayah kesugihan II yang memiliki jumlah penduduk sebanyak 66.378 jiwa dan dengan mayoritas penduduknya berprofesi sebagai buruh. Rasio jumlah penduduk berusia non produktif 47,26 jiwa dan sebagian besar banyak memiliki riwayat penyakit degeneratif.

Posyandu lansia bahagia 5 merupakan salah satu Posyandu yang ada di Desa Slarang Kecamatan Kesugihan Kabupaten Cilacap. Berbagai layanan kesehatan yang diberikan diantaranya pemeriksaan kesehatan, pengukuran tinggi dan berat badan, pengukuran tensi darah, senam khusus lansia, pemberian makanan tambahan dan penyuluhan kesehatan. Berdasarkan wawancara dengan ketua posyandu lansia, tidak kurang 45 sampai 60 lansia aktif yang memanfaatkan posyandu lansia ini yang sebagian besar memiliki penyakit degeneratif seperti Hipertensi, Asam Urat, Diabetes Mellitus, Kolesterol. Dari penyakit degeneratif yang dijumpai di Posyandu lansia Bahagia 5 tersebut, sebagian besar lansia menunjukan adanya risiko mengalami gangguan cairan tubuh.

Berdasarkan hal tersebut di atas penulis bermaksud melakukan pengabdian masyarakat dalam upaya meningkatkan pengetahuan lansia dalam menjaga keseimbangan cairan tubuh dan keterampilan lansia dalam melakukan Pemeriksaan Urin Sendiri (PURI) untuk mengetahui status hidrasi dengan menggunakan kartu PURI. Ketentuan warna urin yaitu apabila warna urin sama dengan warna pada grafik warna urin pada angka 1-3 maka urin lansia terhidrasi dengan baik, 4-8 maka mengalami dehidrasi. Pengabdian ini bertujuan untuk meningkatkan pengetahuan dan keterampilan lansia tentang status cairan tubuh melalui pemeriksaan urin sendiri.

\section{MASALAH}

Mitra adalah kelompok lansia di Posyandu Lansia Bahagia 5 desa Slarang, Puskesmas Kesugihan 2. Permasalahan yang dihadapi mitra dalam pencegahan dan tatalaksana kebutuhan cairan adalah mitra belum mengetahui informasi tentang kebutuhan cairan dan keterampilan dalam pemeriksaan urin sendiri untuk mengetahui status cairan tubuh. 


\section{METODE PELAKSANAAN}

Pengabdian kepada masyarakat ini dilaksanakan di Posyandu Lansia Bahagia 5 Desa Slarang. Sasaran pelaksanaan kegiatan adalah lansia sebanyak 12 orang.

Adapun metode pelaksanaannya adalah sebagai berikut :

a. Upaya peningkatan pengetahuan

1). Pre test

Pada tahap ini dilakukan penilaian pengetahuan Lansia tentang kebutuhan cairan. Instrumen yang digunakan adalah kuesioner dengan menggunakan pernyataan sederhana yang terdiri dari 13 pernyataan benar dan salah sebagai berikut:
a) Sekitar $70 \%$ tubuh manusia terdiri dari air
b) Air yang dikonsumsi berasal dari minuman dan makanan
c) Air berguna untuk mengatur suhu tubuh
d) Air hujan tidak dapat dikonsumsi/diminum
e) Kandungan air pada lansia bertambah seiring bertambahnya usia
f) Penurunan fungsi ginjal salah satu penyebab masalah kebutuhan cairan pada lansia
g) Kulit kering merupakan salah satu tanda kekurangan cairan
h) Suhu tubuh akan turun akibat kekurangan cairan
i) Berkeringat merupakan salah satu pengeluaran air dalam tubuh
j) Warna air kencing coklat tua menandakan kekurangan cairan ringan
k) Keseimbangan antara cairan yang masuk dan keluar dari tubuh disebut dehidrasi
1) Gambaran mengenai cukup atau tidaknya konsumsi cairan didalam tubuh disebut hidrasi
m) Kebutuhan minimal air pada lansia adalah 1,5 liter per hari
2). Pemberian Materi

Pada tahap ini diberikan materi tentang fungsi cairan dalam tubuh, sumber-sumber air minum, faktor yang mempengaruhi kebutuhan cairan pada lansia, masalah kebutuhan cairan pada lansia

3). Post test

Pada tahap ini dilakukan penilaian pengetahuan lansia tentang kebutuhan cairan. Instrumen yang digunakan adalah kuesioner dengan menggunakan pernyataan yang terdiri dari 13 item yang sama pada saat pre test.

b. Upaya peningkatan ketrampilan

Demonstrasi dan pemeriksaan urin lansia menggunakan alat bantu kartu PURI dengan 
cara membandingkan warna urin lansia dengan warna pada kartu PURI. Ketentuan warna urin yaitu apabila warna urin sama dengan warna pada grafik warna urin pada skala 1-3 maka urin lansia terhidrasi baik, dehidrasi ringan skala 4-6 dan dehidrasi berat skala 6-8. Observasi terhadap ketrampilan pemeriksaan urin sendiri pada lansia dengan cara melihat ketepatan hasil pemeriksaan urin dengan benar yang mengacu pada kartu PURI

\section{HASIL DAN PEMBAHASAN}

Hasil kegiatan pengabdian pada lansia di Posyandu Lansia Bahagia 5 Desa Slarang adalah sebagai berikut:

1) Hasil

Hasil pengabdian pada masyarakat ini mencakup karakteristik peserta (jenis kelamin dan usia), tingkat pengetahuan dan hasil pemeriksaan urin.

a. Jenis kelamin.

Jenis kelamin peserta dalam pengabdian ini terdiri dari laki-laki dan perempuan. Adapun hasilnya dapat di deskripsikan dalam diagram 1 berikut:

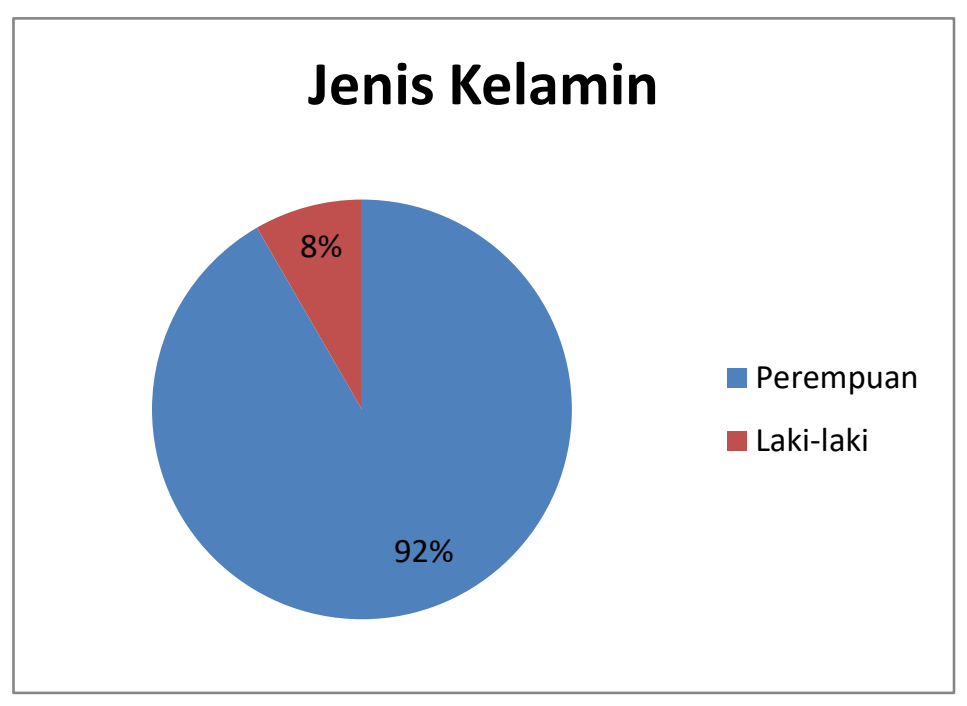

Diagram 1. Jenis kelamin

Berdasarkan diagram 1, jumlah peserta perempuan lebih banyak dari peserta laki-laki yaitu sebanyak 11 orang ( $92 \%$ ) dan laki-laki sebanyak 1 orang (8\%).

b. Usia

Usia peserta pengabdian dikategorikan menjadi 3 berdasar usia dari Depkes, yaitu usia lansia awal (47-55 tahun), lansia akhir (56-65 tahun) dan manula ( $>65$ tahun). Adapun hasilnya dapat dideskripsikan dalam diagram 2 berikut : 


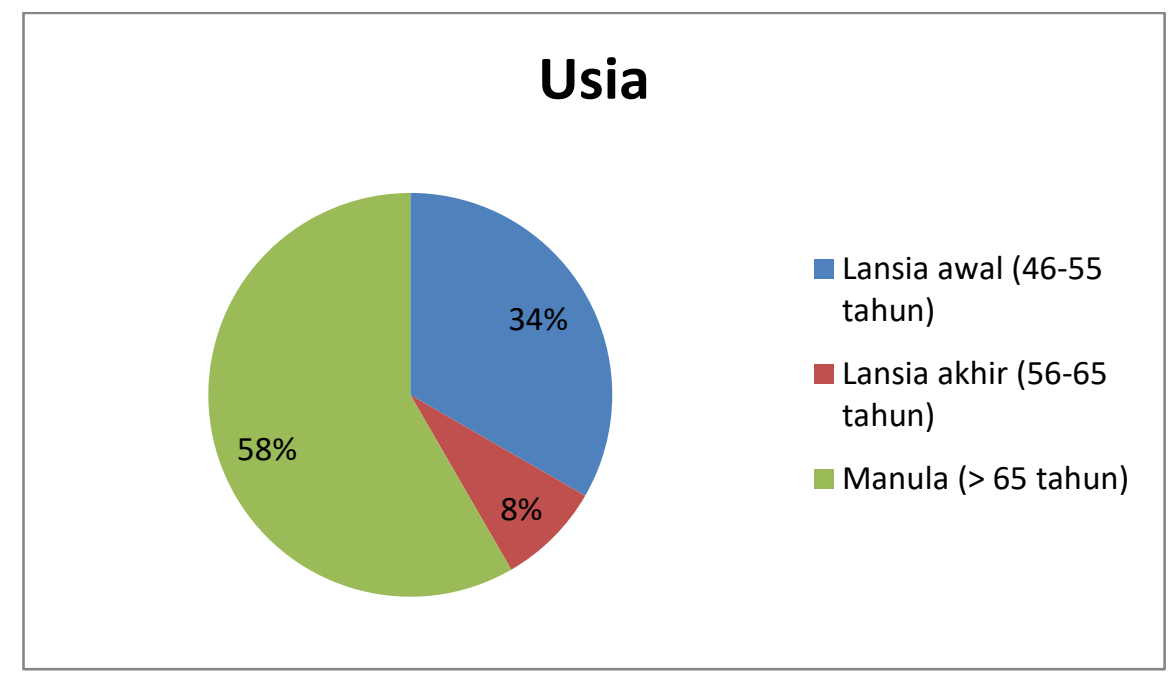

Diagram 2. Usia

Berdasarkan diagram 2, usia peserta paling banyak berusia manula sebanyak 7 orang (58\%) dan paling sedikit berusia lansia akhir sebanyak 1 orang $(8 \%)$.

c. Tingkat Pengetahuan

Pengukuran tingkat pengetahuan menggunakan kuesioner yang berjumlah 13 pertanyaan. Pengukuran tingkat pengetahuan dilakukan dua kali yaitu sebelum dilakukan penyuluhan dan setelah dilakukan penyuluhan. Adapun hasilnya dapat dideskripsikan dalam tabel 3 berikut :

Tabel 1. Tingkat Pengetahuan

\begin{tabular}{lccc}
\hline & Jumlah peserta & Rerata & Persentase \\
\hline Pre Test & 13 & 8,75 & $49 \%$ \\
\hline Post Test & 13 & 9,20 & $51 \%$ \\
\hline
\end{tabular}

Berdasarkan tabel 1, terdapat peningkatan pengetahuan peserta pengabdian yang sebelum dilakukan penyuluhan sebanyak 8,75 (49\%) meningkat setelah dilakukan penyuluhan menjadi $9,20(51 \%)$.

\section{d. Hasil Pemeriksaan Urin}

Pemeriksaaan urin dilakukan dengan melihat satu per satu urin yang di bawa oleh peserta. Selanjutnya, urin di periksa dengan menggunakan kartu PURI dengan cara membandingkan antara warna urin peserta dengan warna pada kartu PURI. Untuk hasilnya dikategorikan menjadi 3 yaitu terhidrasi baik skala 1-3, dehidrasi ringan skala 4-6 dan dehidrasi berat skala 6-8. Adapun hasilnya dapat dideskripsikan dalam diagram 3 berikut : 


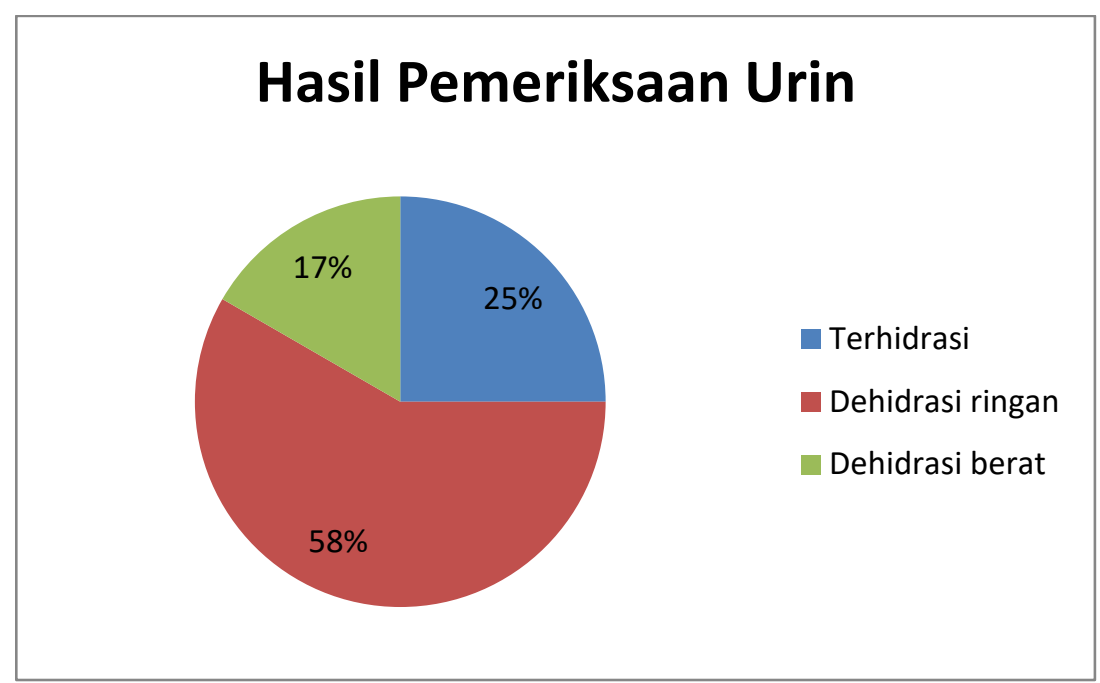

Diagram 3 Hasil Pemeriksaan Urin

Berdasarkan diagram 3, hasil pemeriksaan urin peserta paling banyak mengalami dehidrasi ringan 7 orang (58\%) dan paling sedikit mengalami dehidrasi berat 2 orang (17\%).

\section{2) Pembahasan}

Hasil pengukuran tingkat pengetahuan lansia yang dilakukan sebelum dan setelah penyuluhan menunjukan adanya peningkatan rata-rata nilai post tes dibandingkan dengan nilai rata-rata pre tes. Peningkatan pengetahuan ini kemungkinan dipengaruhi oleh adanya penyuluhan yang dilakukan oleh tim pengabdian. Waktu jeda antara penyuluhan dengan post tes juga sangat dekat yaitu setelah penyuluhan selesai dilakukan penilaian post tes. Menurut Notoatmodjo (2010) menyatakan bahwa dengan memberikan informasi atau pesan-pesan kesehatan kepada masyarakat diharapkan masyarakat, kelompok, atau individu dapat memperoleh pengetahuan tentang kesehatan yang lebih baik. Hal ini sejalan dengan penelitian Yuliaw (2009), bahwa seseorang yang mempunyai tingkat pengetahuan baik akan dapat menjadi guru yang baik bagi dirinya. Selain itu, seseorang yang mempunyai pengetahuan yang lebih luas cenderung mengerti apa dianjurkan oleh petugas kesehatan. Penyuluhan yang dilakukan oleh tim pengabdian merupakan salah satu bentuk pendidikan kesehatan yang diberikan pada lansia secara langsung dengan memberikan informasi tentang status cairan dan cara pemeriksaan urin.

Hasil pemeriksaan urin yang dilakukan tim pengabdian menunjukan bahwa sebagian besar lansia mengalami dehidrasi ringan yang dikarenakan kurangnya asupan cairan. Hasil penelitian Cahyani (2014) menunjukkan bahwa risiko dehidrasi meningkat pada lansia karena perubahan fisiologis pada penuaan, diantaranya cairan tubuh total menurun sehingga walaupun stres ringan seperti cuaca panas akan menyebabkan lansia lebih cepat dehidrasi, 
penurunan asupan cairan yang berhubungan dengan penurunan sensasi haus, penurunan kemampuan dari ginjal untuk mengkonsentrasikan urin. Lansia juga sering mengurangi asupan cairan sebab mereka pikir dengan melakukan hal demikian akan mengurangi frekuensi ke toilet.

Penelitian Schols et al (2009) yang menyatakan bahwa minum saat haus saja tidak cukup karena haus sudah menandakan tubuh mengalami kekurangan cairan, pada lansia juga perlu diingatkan bahwa mereka sebaiknya minum walaupun mereka tidak merasa haus sebab pada mereka terjadi penurunan sensasi rasa haus. Hal ini juga disampaikan oleh tim pengabdiaan saat dilakukan diskusi dengan lansia.

\section{KESIMPULAN}

Setelah dilakukan penyuluhan kepada lansia mengenai kebutuhan dan status cairan, terjadi peningkatan pengetahuan sebanyak 9,20 dibanding sebelum dilakukan penyuluhan sebanyak 8,75. Hasil pemeriksaan urin pada peserta menunjukan sebagian besar lansia mengalami dehidrasi ringan sebanyak 7 orang dan semua lansia sudah dapat melakukan pemeriksaan urin sendiri dengan benar.

\section{DAFTAR PUSTAKA}

Cahyani, V. (2014) Konsumsi Cairan Dan Status Hidrasi Pada Lansia Di Panti Sosial Tresna Werdha Mulia Dharma Kabupaten Kubu Raya. Universitas Tanjungpura.

Fatmah (2010) Gizi Usia Lanjut. Jakarta: Erlangga.

Hardinsyah, Soenaryo ES, Briawan D, Damayanthi E, D. C. and YH, E. (2010) 'Kebiasaan Minum dan Status Hidrasi pada Remaja dan Dewasa di Dua Ekologi yang Berbeda', Department of Community Nutrition Faculty of Human Ecology, IPB Danone-Aqua Indonesia.

Jequier E et al (2010) Water as an Essential Nutrient: the Physiological Basis of Hydration. Eur J Clin Nutr.

Notoatmodjo, S. (2010) Promosi Kesehatan : Toeri dan aPLIKASI. Jakarta: Rineka Cipta.

Nugroho, W. (2000) Keperawatan Gerontik. Jakarta: EGC.

Popkin BM, D’Anci KE, R. I. (2010) Water, Hydration and Health. Nutri Rev.

Schols, J. M. G. A., De Groot, C. P. G. M., Van Der Cammen, T. J. M., \& Rikkert, M. O. (2009) 'Preventing and treating dehydration in the elderly during periods of illness and warm 
weather', JNHA-The Journal of Nutrition, Health and Aging, 13(2), pp. 150-157.

Vivanti AP, Harvey K, A. S. (2010) 'Developing a quick and practical screen to improve the identification of poor hydration in geriatric and rehabilitative care. . 2010';, Arch Gerontol Geriatr, 50(2), pp. 156-164. 